\title{
Isolated Third, Fourth, and Sixth Cranial Nerve Palsies in the Turkish Population: Etiologic Factors and Clinical Course
} Türk Popülasyonunda İzole Üçüncü, Dördüncü ve Altıncı Sinir Felçleri: Etiyolojik
Faktörler ve Klinik Seyir

\author{
(D Ayşe İlksen Çolpak¹, (1) Hale Batur Çă̆layan² \\ ${ }^{1}$ Hacettepe University Faculty of Medicine, Department of Neurology, Ankara, Turkey \\ ${ }^{2}$ Gazi University Faculty of Medicine, Department of Neurology, Ankara, Turkey
}

\begin{abstract}
Objective: To determine the etiologic factors and clinical profile of isolated third, fourth, and sixth nerve palsies in neuro-ophthalmology outpatient clinics of two different reference centers.

Materials and Methods: Retrospective evaluation of medical records from the institutional database.

Results: A total of 127 (78 male, 49 female) patients were analyzed. Forty-five (35.4\%) patients had isolated third nerve palsy, 34 (26.8\%) had isolated fourth nerve palsy, and $48(37.8 \%)$ patients had isolated sixth nerve palsy. The mean ages were similar; $58.87 \pm 13.6,56.32 \pm 16.1$, and $54.9 \pm 14.4$ years, respectively $(\mathrm{p}=0.4)$. Diplopia was the main symptom seen in all patients. Twenty-one patients had anisocoria (20 third, 1 fourth). Among patients with anisocoria, 3 patients had final diagnoses of vasculopathy, the rest were diagnosed as having acquired non travmatic palsy with different etiologies such as aneurysm, Tolosa-Hunt syndrome, and carotico-cavernous fistula. The most common etiology for all groups was vasculopathy. Three patients with isolated oculomotor nerve palsy were diagnosed as having Tolosa-Hunt sydnrome despite pupillary sparing. The mean recovery time was similar for all cranial nerve palsies.
\end{abstract}

Conclusion: Although, the most common etiology of third, fourth, and sixth nerve palsies is vasculopathy, neuroimaging studies are crucial to exclude potentially treatable and dangerous conditions.

Keywords: Diplopia, third nerve palsy, fourth nerve palsy, sixth nerve palsy

$\ddot{O} \mathbf{z}$

Amaç: İki farklı referans merkezin nöro-oftalmoloji polikliniklerinde izlenen, izole üçüncü, dördüncü ve altıncı kraniyal sinir felçlerinin etiyolojik faktörleri ve klinik profillerinin tespit edilmesidir.

Gereç ve Yöntem: Hasta kayıtlarının geriye dönük olarak taranmasıdır.

Bulgular: Toplamda 127 hasta (78 erkek, 49 kadın) incelendi. Kırk beş hastanın $(\% 35,4)$ izole üçüncü sinir felci, 34 hastanın (\%26,8) izole dördüncü sinir felci ve 48 hastanın $(\% 37,8)$ izole altıncı sinir felci vardı. Ortalama yaşlar benzerdi, sırasıyla: 58,87 $( \pm 13,6), 56,32( \pm 16,1)$ ve 54,9 ( $\pm 14,4)$ olarak saptandı $(\mathrm{p}=0,4)$. Ana semptom çift görme olup, tüm hastalarda izlendi. Yirmi bir hastanın anizokorisi vardı (20 üçüncü, 1 dördüncü sinir). Anizokorisi olan hastalardan 3 tanesi vaskülopatiye bağlı üçüncü sinir felciydi, diğerleri edinilmiş non-travmatik grup olarak kabul edildi ve etiyolojilerinde anevrizma, Tolosa-Hunt sendromu, C

karotiko-kavernöz fistül gibi tanılar vardı. Tüm hasta gruplarında en sık saptanan etiyoloji vaskülopati idi. Üç hasta pupilin korunduğu üçüncü sinir felci olmasına rağmen Tolosa-Hunt sendromu tanısı aldı. Tüm sinirler için düzelme zamanı benzerdi.

Sonuç: Her ne kadar üçüncü, dördüncü ve altıncı sinir felçlerinin en sık etiyolojik sebebi vaskülopati olsa da, tedavi potansiyeli olan ve tehlikeli durumların dışlanabilmesi için nöro-görüntüleme çalışmaları önemlidir.

Anahtar Kelimeler: Çift görme, üçüncü sinir felci, dördüncü sinir felci, altıncı sinir felci

Address for Correspondence/Yazışma Adresi: Ayse İlksen Çolpak MD, Hacettepe University Faculty of Medicine, Department of Neurology, Ankara, Turkey Phone: +90 5326945996 E-mail: ilksenisikay@yahoo.com.tr ORCID ID: orcid.org/0000-0002-7444-2640

Received/Geliş Tarihi: 24.01.2019 Accepted/Kabul Tarihi: 08.02.2019

${ }^{\circ}$ Copyright 2019 by Turkish Neurological Society

Turkish Journal of Neurology published by Galenos Publishing House. 


\section{Introduction}

Ocular motor nerve palsies are the main reasons of diplopia and one of the most common referrals to neuro-ophthalmology outpatient clinics after visual loss. Although the prognosis is good, defining the cause is critical for follow-up, and early recognition of serious and potentially treatable diagnoses are mandatory (1).

Microvascular ischemia of the nerve is considered to be the most likely cause in patients with acute onset third, fourth or sixth nerve palsy aged over 50 years with atherosclerotic risk factors. It still remains controversial as to whether neuroimaging should be performed at the time of diagnosis or to wait 3 months for spontaneous recovery (2).

Although a considerable number of large retrospective studies have been performed, the number of studies in Turkish patients is low $(3,4,5)$.

In this study, the clinical profile of patients with isolated third, fourth, and sixth nerve palsies was studied to assess the common diagnoses and etiologic factors of the Turkish population encountered in the neuro-ophthalmology outpatient clinics at two reference centers.

\section{Materials and Methods}

\section{Data Collection}

We reviewed the medical records of patients with diagnoses of isolated third, fourth, and sixth cranial nerve palsies, in neuro-ophthalmology outpatient clinics of Hacettepe and Gazi University Hospitals, between March 2014 and September 2018. This retrospective study was approved by the Ethics Committee of Hacettepe University Faculty of Medicine (protocol number: GO18/677-26), in accordance with the Declaration of Helsinki. All patients were examined and followed up by the authors of this manuscript personally, at each center.

Patients aged $\geq 18$ years with isolated partial or complete ocular motor nerve palsy with no other neurologic signs and symptoms other than periorbital pain were included in the study.

Demographic information, including age and sex, medical history prior to neurologic disease, diabetes mellitus (DM), hypertension, hypercholesterolemia, coronary arterial disease, thyroid disease, and history of other systemic illnesses were recorded. Visual acuity (using Snellen chart), pupillary examination, visual fields by confrontation, assessment of ptosis, alternate cover test, examination of eye movements, Maddox-Rod test (in the event of non-obvious ocular motility disorder), and fundus examinations were perfomed.

Results of single-fiber electromyography, erythrocyte sedimentation rate, imaging studies such as magnetic resonance imaging (MRI), carotid and cerebral computed tomography angiography (CCTA) were recorded.

Patients were etiologically classified as: vasculopathic, traumatic, acquired non-traumatic, congenital and undetermined (6). The vasculopathic group had at least one vascular risk factor with normal/non-specific MRI and no history of trauma or congenital findings. The acquired non-traumatic group consisted of cranial nerve palsies with lesions localized anywhere along the course from the brainstem to the orbit. Patients who had no vasculopathic risk factors and had completely normal MRI were classified as undetermined.

\section{Statistical Analysis}

Statistical analyses were performed using Wizard 1.9.18 for MacOS. Numeric variables are presented as mean \pm standard deviation, and categorical variables are presented as frequencies and percentages. Categorical variables were compared using the chi-square test, and continuous variables were compared using the Mann-Whitney $U$ test. A p value of less than 0.05 was considered statistically significant.

\section{Results}

The medical records of patients with the diagnosis of third, fourth, and sixth nerve palsies between March 2014 to September 2018 were evaluated for participation in the study. One hundred thirty-two patients had complete medical records, including history, examination, and laboratory analyses. Five of these 132 patients had multiple cranial neuropathies and were excluded.

A total of 127 (78 male, 49 female) patients were analyzed. Forty-five patients $(35.4 \%)$ had isolated third nerve palsy, 34 $(26.8 \%)$ had isolated fourth nerve palsy, and 48 patients $(37.8 \%)$ had isolated sixth nerve palsy. The mean ages were similar: $58.87 \pm 13.6,56.32 \pm 16.1$, and $54.9 \pm 14.4$ years, respectively $(\mathrm{p}=0.4)$.

Diplopia was the main symptom seen in all patients. In 15 patients with accompanying periorbital pain, the diagnoses were third $(n=7)$ and sixth $(n=8)$ nerve palsies. Nine patients had ptosis and all of them had third nerve palsies. Twenty-one patients had anisocoria; one of these patients had fourth nerve palsy due to carotico-cavernous fistula (CCF), and the rest had third nerve palsy. Among patients with anisocoria, only 3 patients had final diagnoses of vasculopathy, the remainder was diagnosed as having acquired non-traumatic palsy with different etiologies such as aneurysm, Tolosa-Hunt syndrome (THS), CCF, leptomeningeal carsinomatosis, lymphoma, mucormycosis, herpes zoster, and menengioma. Three patients with pupilsparing isolated oculomotor nerve palsy and were diagnosed as having THS.

The most common etiology for all groups was vasculopathy, which was seen in 21 patients $(35.6 \%)$ with third nerve palsies, $15(25.4 \%)$ with fourth nerve palsies, and $23(39 \%)$ patients with sixth nerve palsies. The number of patients in the acquired nontraumatic group was low in fourth nerve palsies $(5.9 \%)$ compared with third $(40 \%)$ and sixth $(25 \%)$ nerve palsies $(\mathrm{p}=0.003)$. The etiologic causes in all patients are summarized Table 1.

Only the vasculopathic group were older than other etiologic groups and this finding was statistically significant $(\mathrm{p}<0.001)$ (Table 2). Among those with the etiology of vasculopathy, age 50 seemed to be a determinant for only sixth nerve palsies $(\mathrm{p}=0.04)$ (Table 3). Risk factors for each cranial nerve are summarized in Table 4.

One hundred twelve patients had long-term follow-up; 33 patients had uela, and 79 patients recovered completely. The recovery times for patients with third, fourth, and sixth nerve palsy did not differ signficantly. Eight patients with third nerve palsy, 18 patients with fourth nerve palsy, and 6 patients with 
Table 1. The etiologic causes in all patients

\begin{tabular}{llll|} 
& $\begin{array}{l}\text { Third nerve } \\
\text { palsy (n) }\end{array}$ & $\begin{array}{l}\text { Fourth nerve } \\
\text { palsy (n) }\end{array}$ & $\begin{array}{l}\text { Sixth nerve } \\
\text { palsy (n) }\end{array}$ \\
Vasculopathic & 21 & 15 & 23 \\
$\begin{array}{l}\text { Acquired non- } \\
\text { traumatic }\end{array}$ & 18 & 2 & 12 \\
Traumatic & - & 3 & - \\
Congenital & - & 8 & 1 \\
Undetermined & 6 & 6 & 12 \\
\hline
\end{tabular}

Table 2. The number of patients according to age 50 in all etiological groups. Patients in vasculopathic group were older

\begin{tabular}{lll|} 
& $\begin{array}{l}\text { Age } \leq 50 \\
\text { years (n) }\end{array}$ & $\begin{array}{l}\text { Age }>50 \\
\text { years (n) }\end{array}$ \\
Vasculopathic* & 7 & 52 \\
Acquired non-traumatic & 14 & 18 \\
Congenital & 5 & 4 \\
Undetermined & 9 & 14 \\
"p $<0.001$ & & \\
\hline
\end{tabular}

Table 3. Patients with the etiology of vasculopathy

\begin{tabular}{|llll|} 
& $\begin{array}{c}\text { Age } \leq 50 \\
\text { years (n) }\end{array}$ & $\begin{array}{l}\text { Age }>50 \\
\text { years (n) }\end{array}$ & p value \\
Third nerve palsy & 2 & 19 & 0.057 \\
Fourth nerve palsy & 2 & 13 & 0.071 \\
$\begin{array}{l}\text { Sixth nerve palsy* } \\
\text { *Age 50 years was a determinant for only sixth nerve palsies in our study group } \\
(\mathrm{p}=0.047)\end{array}$ \\
\hline
\end{tabular}

\begin{tabular}{|llll|}
\hline \multicolumn{4}{|l}{ Table 4. Risk factors of patients according to ocular motor } \\
nerve palsies & $\begin{array}{l}\text { Third } \\
\text { nerve (n) }\end{array}$ & $\begin{array}{l}\text { Fourth } \\
\text { nerve (n) }\end{array}$ & $\begin{array}{l}\text { Sixth } \\
\text { nerve (n) }\end{array}$ \\
\hline Diabetes mellitus & 22 & 9 & 14 \\
Hypertension & 19 & 15 & 25 \\
Coronary arterial disease & 2 & 7 & 8 \\
Hyperlipidemia & 10 & 5 & 12 \\
Thyroid disease & 2 & - & 2 \\
\hline
\end{tabular}

sixth nerve palsy showed no recovery. The fourth nerve was the least recovering cranial nerve, but it is noteworthy to mention that 8 were diagnosed as congenital. The mean recovery time for oculomotor, trochlear, and abducens nerve were 85.83 \pm 50.16 , $85 \pm 37.53,97.78 \pm 66.47$ days, respectively.

In our study, 120 patients had MRI or CCTA, and only 7 patients had no neuroimaging. Twenty-one patients had ischemic gliotic lesions, 71 patients had non-significant neuroimaging findings, and 28 patients had various MRI findings mostly affecting the cavernous sinus.

\section{Discussion}

A retrospective review of patients with isolated third, fourth, and sixth nerve palsies was performed in the neuro-ophthalmology outpatient clinics of two reference centers. This study demonstrated that vasculopathy is the leading etiologic diagnosis in Turkish patients and the time for recovery for third, fourth, and sixth nerve palsies were similar.

Sixth nerve palsies in our study group were slightly higher than in third and fourth nerve palsies, as with most series with large number of patients in the literature $(3,7,8,9)$. It is not clear which one is more common, but it is clear that fourth nerve palsies are not as common as third and sixth nerve palsies $(1,8,10)$. Although acquired non-traumatic etiology is not common in fourth nerve palsies and was seen in only 2 patients in our study, both emerged due to cavernous sinus lesions (leiomyosarcoma metastasis and CCF). The patient with leiomyosarcoma was a 68-year-old male with vascular risk factors and had no associated cranial findings other than fourth nerve palsy. The patient might have been accepted as vasculopathic fourth nerve palsy if no imaging was performed. The second patient was diagnosed as having CCF and was treated with embolization at the time of diagnosis.

The decision for neuroimaging was critical for these patients. Likewise, sixth nerve palsies with no atherosclerotic risk factors $(n=8)$ had diagnoses of life-threatening and treatable disorders through neuroimaging.

A well recognized and believed principle in third nerve palsies is "the third nerve rule". Most pupil-sparing third nerve palsies are believed to result from microvascular ischemia of the nerve and mainly associated with DM. However, there is a considerable number of patients with vasculopathic third nerve palsy with pupil involvement, perhaps as many as $38 \%$ of cases. The main limitation of this finding in the literature is the inadequate evalution of size of the pupil. Pupil dilation may be overlooked, because most of the time it is $\leq 1 \mathrm{~mm}(2,11)$. Recently, the abnormal pupillary constriction ratio was claimed as the most promising specific parameter for detecting compressive third nerve palsies (12). In our study, 3 patients were against "rule" and had pupil-involved third nerve palsy with vasculopathic etiology $(6 \%)$.

Rarely, the opposite, "pupil-sparing compressive third nerve palsies", can be seen. In our study, we had 3 patients with acquired non-traumatic third nerve palsies diagnosed as THS and no pupil involvement was noticed $(2,13)$. Although THS is not a compressive lesion, it is a non-specific inflammation confined to the septa and wall of the cavernous sinus, and most of the time pupillary involvement may be present due to injury to the sympathetic fibers in the cavernous portion of internal carotid artery or parasympathetic fibers that surround the oculomotor nerve.

The diagnostic value of having complete or partial paralysis, such as pupil involvement, is still controversial. Both complete and partial third nerve palsies might be due to aneurysms and neuroimaging should be performed (2).

In this study, the most common atherosclerotic risk factor for the vasculopathic group was hypertension, followed by DM in fourth and sixth nerve palsies. DM was the leading risk factor 
in third nerve palsies, followed by hypertension. In our study, 27 patients had both hypertension and DM at the same time in a total of 59 vasculopathic ocular motor nerve palsies. The risk of developing an ocular motor cranial nerve palsy was found to be 10 times higher in patients with diabetes than in the nondiabetic control group, in a retrospective study of ocular motor nerve palsies (14). In a prospective study with acute isolated ocular motor nerve palsies in patients aged 50 years or older, the need for neuroimaging in older patients is highlighted regardless of whether vascular risk factors are present (15).

\section{Study Limitations}

In our study, the results are limited because of the small sample size and retrospective nature of the study. Another limitation is that we did not look for glucose intolerance or ambulatory blood pressure monitoring in our patients. We had a considerable number of patients in the undetermined group with no risk factors and these patients might have had glucose intolerance or masked hypertension. Moreover, because the patients were recruited from neuro-ophthalmology clinics, and most of the patients were referred from other physicians, the probability of serious causes were relatively high because ophthalmologists in particular have a tendency to refer patients with atypical findings and prolonged recovery time. It is also important to note that most of the neuroimaging was performed at the centers that referred the patients.

\section{Conclusion}

Although, the most common etiology of third, fourth, and sixth nerve palsies is vasculopathy, neuroimaging studies are crucial for excluding sinister conditions such as aneurysms, neoplasms or potentially treatable diseases in the modern era. With the advances in neuroimaging, further prospective studies with a large number of patients, including pupillary measurements as well as a comparison with young patients may better illustrate the best approach to ocular motor nerve palsies.

Ethics

Ethics Committee Approval: The study and the protocols were approved by the Ethics Committee of Hacettepe University Faculty of Medicine, Ankara, Turkey (protocol number: GO18/677-26).

Informed Consent: All patients were examined and followed up by the authors of this manuscript personally, at each center.

Peer-review: Internally peer-reviewed.

\section{Authorship Contributions}

Surgical and Medical Practices: A.İ.Ç., H.B.Ç., Concept: A.İ.Ç., H.B.Ç., Design: A.İ.Ç., H.B.Ç., Data Collection or Processing: A.İ.Ç., H.B.Ç., Analysis or Interpretation: A.İ.Ç., Literature Search: A.İ.Ç., Writing: A.İ.Ç., H.B.Ç.

Conflict of Interest: No conflict of interest was declared by the authors.

Financial Disclosure: The authors declared that this study received no financial support.

\section{References}

1. Berlit P. Isolated and combined pareses of cranial nerves III, IV and VI. A retrospective study of 412 patients. J Neurol Sci 1991;103:10-15.

2. Volpe NJ, Lee AG. Do patients with neurologically isolated ocular motor cranial nerve palsies require prompt neuroimaging? J Neuroophthalmol 2014;34:301-305.

3. Nalcacioğlu P, Kavuncu S, Budakoğlu Ö, İlhan B, Acaroğlu G. Ocular motor nerve palsies: 225 clinical and etiological analysis. Turkiye Klinikleri J Ophthalmol 2016;25:238-244.

4. Özbek Z, Berk AT, Hızlı T, Akman F. Oculomotor, trochlear and abducens nerve palsies in children. Turkiye Klinikleri J Ophthalmol 2003;12:139-144.

5. Şekeroğlu HT, Turan KE, Umut A, Şener EC, Sanac AS. Etiology of Fourth and Sixth Nerve Palsies: A single Ophthalmology Clinic's Perspective. Int J Ophthalmol Clin Res 2014;1:1.

6. Brazis PW. Isolated palsies of cranial nerves III, IV, and VI. Semin Neurol 2009;29:14-28.

7. Rush JA, Younge BR. Paralysis of cranial nerves III, IV, and VI. Cause and prognosis in 1,000 cases. Arch Ophthalmol 1981;99:76-79.

8. Park UC, Kim SJ, Hwang JM, Yu YS. Clinical features and natural history of acquired third, fourth, and sixth cranial nerve palsy. Eye (Lond) 2008;22:691-696.

9. Richards BW, Jones FR Jr, Younge BR. Causes and prognosis in 4,278 cases of paralysis of the oculomotor, trochlear, and abducens cranial nerves. Am J Ophthalmol 1992;113:489-496.

10. Batocchi AP, Evoli A, Majolini L, et al. Ocular palsies in the absence of other neurological or ocular symptoms: analysis of 105 cases. J Neurol 1997;244:639-645.

11. Trobe JD. Third nerve palsy and the pupil. Footnotes to the rule. Arch Ophthalmol 1988;106:601-602.

12. Kim HM, Yang HK, Hwang JM. Quantitative analysis of pupillometry in isolated third nerve palsy. PLoS One 2018;13:e0208259.

13. O'Connor PS, Tredici TJ, Green RP. Pupillary-sparing third nerve palsy due to aneurysm: a survey of 2419 neurological surgeons. J Neurosurg 1983;58:792-793.

14. Jung JS, Kim DH. Risk factors and prognosis of isolated ischemic third, fourth, or sixth cranial nerve palsies in the Korean population. J Neuroophthalmol 2015;35:37-40.

15. Tamhankar MA, Biousse V, Ying GS, et al. Isolated third, fourth, and sixth cranial nerve palsies from presumed microvascular versus other causes: a prospective study. Ophthalmology 2013;120:2264-2269. 